Doi: HTTPS://DOI.ORG/10.23910/IJEP/2019.6.3.0326

\title{
Assessment of Yield Gaps in Chickpea Production in Shimla District of Himachal Pradesh
}

\author{
Neelam Kumari*, Ashok K. Thakur and N. S. Kaith
}

Dr Y S Parmar University of Horticulture and Forestry, Krishi Vigyan Kendra Shimla, Rohru, H.P. (171 207), India

\section{Corresponding Author}

Neelam Kumari

e-mail: neelkumari90@gmail.com
Article History

Article ID: IJEP0326

Received in $13^{\text {th }}$ August, 2019

Received in revised form $20^{\text {th }}$ August, 2019

Accepted in final form $28^{\text {th }}$ August, 2019

\begin{abstract}
Though substantial progress has been made in evolving techniques to obtain high yields of pulses, however, their productivity has remained lower than the potential yields for the last few decades. Acreage and productivity of pulse crop is declining in Himachal Pradesh and Shimla district as well. To boost the production and productivity of pulse crops, Krishi Vigyan Kendra Shimla is conducting cluster frontline demonstrations (CFLD) on pulse crops. The main objective of CFLD on pulses is to demonstrate and popularize the improved technologies on farmers' fields for effective transfer of generated technology and fill the gap between recommended practices and farmers' practices and ultimately to boost the production of pulses. Frontline demonstrations in chickpea during rabi season were studied for four years (Rabi 2015-16, Rabi 2016-17, Rabi 2017-18 and Rabi 2018-19) in Shimla district of Himachal Pradesh. There was a wide yield gap between the potential and demonstration yields mainly due to technology and extension gaps. CFLD on chickpea crop indicated that increase in yield over farmers' practice ranged from 22.22 to $68.44 \%$ over four years. In terms of economics, chickpea crop recorded higher net returns hectare $^{-1}$ compared to farmer's practice during all the years. The benefit:cost ratio of demonstration plots ranged from 1.21 to 2.63 . The technology index varied from 10.29 to $45.00 \%$ indicating the urgent need to motivate the farmers to adopt economical viable technologies for increasing production, productivity and profitability of chickpea.
\end{abstract}

Keywords: Chickpea, economic analysis, technology index

\section{Introduction}

Pulses are important component of Indian agricultural economy next to food grains and oilseeds in terms of acreage, production and economic value (Choudhary, 2009). Pulse production in India has fluctuated widely leading to steady decline in the per capita availability over last 20 years (Gregory et al., 2003). In India, pulses are grown on an area of 9.54 million hectare with an annual production of 9.08 million tonnes (GOI, 2016). The productivity of pulses in Himachal Pradesh continues to be quite low over the years because of their cultivation under rainfed conditions on less productive lands with no or little inputs compared to those used for cereals. Thus, there is a great challenge for policy makers, farm scientists, extension functionaries and farming community to enhance pulse productivity and diversify their cropping systems to meet out the national and local pulse requirements.

Shimla district of Himachal Pradesh is situated between $30^{\circ} 45^{\prime}$ and $31^{\circ} 44^{\prime}$ North latitude and $77^{\circ} 0^{\prime}$ and $78^{\circ} 19^{\prime}$ East longitude with an elevation varying from 600 meters to 6000 meters amsl. Out of three main pulse crops i.e. black gram (Vigna mungo), rajmash (Phaseolus vulgaris) and chickpea (Cicer arietinum), chickpea is only rabi season pulse crops grown by the farmers of the district. The productivity of pulses in the district is quite low compared to national and global average, mainly due to their cultivation under rainfed and marginal lands besides poor crop management practices (Choudhary, 2009). Besides this, lack of technical knowledge, unavailability of quality seed and non-adoption of plant protection measures further aggravate the problem of poor productivity in the district (Paul et al., 2011). There exists a wide yield gaps in between the experimental plots, frontline demonstrations plots and farmers fields.

Keeping in view the above facts, present investigation was undertaken to demonstrate and transfer the generated farm technology through CFLD on pulses under rainfed production systems with the objectives of enhancing productivity, profitability and narrowing extension yield gaps. Technological and extension yield gaps under pulses in this comprehensive study are also presented in this paper for framing appropriate extension strategy for effective transfer of technology to target farmers in the district and collateral socio-agro-economic environments of north-western Himalayas for sustaining the pulse production systems. 


\section{Materials and Methods}

\subsection{Yield increase}

CFLDs on pulse crop chickpea were conducted by KVK Shimla of Himachal Pradesh during Rabi 2015-2018 for consecutive four years. A total of 50 ha area was covered under CFLDs on chickpea under rainfed conditions in 24 villages on 363 farmers' fields during all the years under study. In frontline demonstrations, full package of practices were adopted whereas in the farmers' practice, existing practices being used by the farmers of the area were followed (Table 1). The primary data on yield and farmers' practice was collected from the beneficiary farmers. The yield increase in demonstrations over farmers' practice (YIOFP) was calculated by using the following formula:

YIOFP $(\%)=$ (Demonstration plot yield-Farmer's plot yield/ farmer's plot yield) $\times 100$

Table 1: Comparison of recommended practices demonstrated and farmers' practice in chickpea technologies in Shimla district of Himachal Pradesh

\begin{tabular}{|c|c|c|}
\hline Crop operation & $\begin{array}{l}\text { Recommended } \\
\text { Practices demon- } \\
\text { strated }\end{array}$ & Farmers' Practice \\
\hline Variety & $\begin{array}{l}\text { HC-1, HC-5, GNG- } \\
1581\end{array}$ & Local (Land Race) \\
\hline $\begin{array}{l}\text { Land prepara- } \\
\text { tion }\end{array}$ & Two ploughings & One ploughing \\
\hline Seed rate & $40 \mathrm{~kg} \mathrm{ha}^{-1}$ & $50 \mathrm{~kg} \mathrm{ha}^{-1}$ \\
\hline $\begin{array}{l}\text { Method of sow- } \\
\text { ing }\end{array}$ & Line sowing & Broadcasting \\
\hline Time of sowing & Mid October & Mid October \\
\hline Fertilizer dose & $\begin{array}{l}30: 60: 30 \mathrm{Kg} \text { NPK } \\
\mathrm{ha}^{-1}\end{array}$ & No fertilizer use \\
\hline $\begin{array}{l}\text { Weed manage- } \\
\text { ment }\end{array}$ & Hand weeding & Hand weeding \\
\hline Plant protection & $\begin{array}{l}\text { Need based pesti- } \\
\text { cide application }\end{array}$ & $\begin{array}{l}\text { No pesticide ap- } \\
\text { plication }\end{array}$ \\
\hline Irrigation & Rainfed & Rainfed \\
\hline
\end{tabular}

2.2. Assessment of technology gap, extension gap and technology index

The estimation of technology gap, extension gap and technology index was done using following formula (Samui et al., 2000):

i) Technology gap=Potential yield-Demonstration plot yield ii)Extension gap=Demonstration plot yield-Farmer' s plot yield iii)Technology index (\%) $=(\mathrm{Pi}-\mathrm{Di}) / \mathrm{Pi} \times 100$

Where,

$\mathrm{Pi}=$ Potential yield of ith crop
$\mathrm{Di}=$ Demonstration yield of ith crop

\subsection{Economic analysis of cluster FLD on chickpea}

Cost of cultivation of chickpea include cost of inputs like seed, fertilizers, pesticides etc. not available with the farmers and purchased by the farmers (in farmers practice) or supplied by the KVK (in recommended practice) as well as hired labour (if any), sowing charges by bullocks or tractor (if any) and post harvest operation charges (if any) paid by the farmers. The family labour was not taken into consideration in the present study. The gross and net returns were worked out accordingly by taking cost of cultivation and price of grain yield of respective crop into consideration. Additional costs in frontline demonstrations include expenditure on improved technological inputs in frontline demonstrations over farmers' practice. Similarly, benefit:cost ratio was worked out as a ratio of returns and corresponding costs.

\section{Results and Discussion}

\subsection{Yield}

Perusal of the data in Table 2 revealed that with the adoption of recommended practices in frontline demonstration of pulse crops, the yield can be raised by 22.22 to $68.44 \%$ in chickpea over the farmers' practice. This superiority of recommended practices in frontline demonstration over farmers' practice was also reported by Sagar and Chandra (2004), Vaghasia et al. (2005), Mitra and Samajdar (2010) and Balai et al. (2012). The year to year fluctuation in yield and cost of cultivation can be explained on the basis of variation in prevailing social, economical and microclimatic conditions of that particular village.

\subsection{Technology gap, extension gap and technology index}

The technological gap shows the gap in the recommended practices in frontline demonstration's yield over potential yield and it ranged from 2.46 to $4.95 \mathrm{q} \mathrm{ha}^{-1}$ in chickpea (Table 2). The observed technology gap may be attributed to dissimilarity in soil fertility status and weather conditions. Similar findings were documented by Hiremath and Nagaraj (2009). Hence, to narrow down the gap between the yield of recommended practices and farmers' practice location specific recommendation appears to be necessary.

The extension gap which ranged from 1.10 to $6.91 \mathrm{q} \mathrm{ha}^{-1}$ in chickpea during the period of study emphasized the need to educate the farmers through various means for the adoption of recommended and improved agricultural production technologies to reverse this trend of wide extension gap. The feasibility of the evolved technology in the farmer's fields is indicated by the technology index. The lower the technology index more is the feasibility of the technology (Mishra et al., 2007). In chickpea crop, technology index varied from 10.29 to $45.00 \%$. As the crop was grown under rain fed conditions, 


\begin{tabular}{|c|c|c|c|c|c|c|c|c|c|c|}
\hline $\begin{array}{l}\text { Season and } \\
\text { year }\end{array}$ & Variety & $\begin{array}{l}\text { Area } \\
\text { (ha) }\end{array}$ & $\begin{array}{l}\text { No. of } \\
\text { farmers }\end{array}$ & $\begin{array}{l}\text { No. of } \\
\text { villages }\end{array}$ & $\begin{array}{c}\text { Yield } \\
\left(\mathrm{q} \mathrm{ha} \mathrm{h}^{-1}\right) \\
\mathrm{DP}^{*} \\
\end{array}$ & 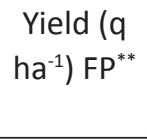 & $\begin{array}{c}\text { Yield } \\
\text { increase } \\
(\%)\end{array}$ & $\begin{array}{l}\text { Technology } \\
\text { gap }\left(q \text { ha }^{-1}\right)\end{array}$ & $\begin{array}{l}\text { Extension } \\
\text { gap }\left(q \text { ha }^{-1}\right)\end{array}$ & $\begin{array}{c}\text { Technol- } \\
\text { ogy in- } \\
\operatorname{dex}(\%)\end{array}$ \\
\hline Rabi 2015-16 & $\mathrm{HC}-1$ & 25 & 125 & 7 & 8.54 & 5.07 & 68.44 & 2.46 & 3.47 & 22.36 \\
\hline Rabi 2016-17 & $\mathrm{HC}-1$ & 5 & 69 & 5 & 6.05 & 4.95 & 22.22 & 4.95 & 1.10 & 45.00 \\
\hline Rabi 2017-18 & HC-5 & 10 & 68 & 6 & 7.06 & 5.39 & 30.98 & 3.94 & 1.67 & 35.82 \\
\hline Rabi 2018-19 & GNG-1581 & 10 & 101 & 6 & 21.53 & 14.62 & 47.26 & 2.47 & 6.91 & 10.29 \\
\hline
\end{tabular}

*DP: Front line demonstration plots; **FP: Farmers practice Plots

lack of irrigation facilities particularly in rabi season when very little rains occur in the district leads to higher technology index during rabi season chickpea crop. Moreover, reduction of technology index in general over the year of study clearly exhibited the feasibility of technologies demonstrated in frontline demonstrations.

\subsection{Economic analysis}

The economic analysis of the data (Table 3 ) for the study period for chickpea clearly revealed that the gross return, net returns and benefit: cost ratios were higher in frontline demonstrations where recommended practices were followed as compared to farmers' practice indicating higher profitability. The benefit cost ratios of demonstration plots ranged from 1.21 to 2.63 in chickpea. Similar findings were also reported by Kumari et al. (2007).

\begin{tabular}{|c|c|c|c|c|c|c|c|c|}
\hline \multirow{2}{*}{$\begin{array}{l}\text { Season and } \\
\text { year }\end{array}$} & \multicolumn{2}{|c|}{ Cost of Cultivation ( $₹$ ha $^{-1}$ ) } & \multicolumn{2}{|c|}{ Gross Returns (₹ ha-1) } & \multicolumn{2}{|c|}{ Net Returns (₹ ha $\left.{ }^{-1}\right)$} & \multicolumn{2}{|c|}{ B:C Ratio } \\
\hline & $\mathrm{DP}^{*}$ & $\mathrm{FP}^{* *}$ & $\mathrm{DP}^{*}$ & $\mathrm{FP}^{* *}$ & $\mathrm{DP}^{*}$ & $\mathrm{FP}^{* *}$ & $\mathrm{DP}^{*}$ & $\mathrm{FP}^{* *}$ \\
\hline Rabi 2015-16 & 12950 & 13900 & 46970 & 20680 & 34020 & 6780 & 2.63 & 0.49 \\
\hline Rabi 2016-17 & 7917 & 9300 & 19880 & 16988 & 11963 & 7688 & 1.51 & 0.82 \\
\hline Rabi 2017-18 & 7000 & 9300 & 15500 & 14000 & 8500 & 4700 & 1.21 & 0.50 \\
\hline Rabi 2018-19 & 6500 & 8800 & 20500 & 14000 & 14000 & 5200 & 2.15 & 0.60 \\
\hline
\end{tabular}

*DP: Front line demonstration plots; **FP: Farmers practice Plots

\section{Conclusion}

The yield of chickpea crop can be increased to a greater extent even under rain fed situations by adopting the recommended practices and improved technology in Shimla district of Himachal Pradesh. Favourable benefit: cost ratio is self explanatory of economic viability of the frontline demonstrations and encouraged the farmers for adoption of interventions imparted. It is also observed that higher extension gap emphasized that there is further need to educate the farmers for adoption of improved technologies so that poor farmers with limited resources could improve their livelihood and diversify their farming situation.

\section{References}

Balai, C.M., Meena, R.P., Meena, B.L., Bairwa, R.K., 2012. Impact of frontline on rapeseed and mustard yield improvement. Indian Research Journal of Extension Education 12, 113-116.

Choudhary, A.K., 2009. Role of phosphorus in pulses and its management. Indian Farmers' Digest 42, 32-34.

Gregory, K., Price, L.R., Govindan, A., 2003. India's Pulse sector:
Results of Field Research. Electronic Outlook Report of Economic Research Service, USDA. WRS-03-01, May, 2003, 1-23.

GOI., 2016. Directorate of Economics and Statistics, Ministry of Agriculture, Government of India. Avaialable from http://www.dacnet.nic.in/ean.

Hiremath, S.M., Nagaraju, M.V., 2009. Evaluation of demonstration trials on onion in Haveri district of Karnatka. Karnatka Journal of Agricultural Sciences 29, 1092-1093.

Kumari, V., Kumar, A., Kumar, A., Bhateria, S., 2007. Demonstration- an effective tool for increasing the productivity of rape seed-mustard in Kangra district of Himachal Pradesh. Himachal Journal of Agricultural Research 33, 257-261.

Mishra, D.K., Tailor, R.S., Pathak, G., Deshwal, A., 2007. Yield gap analysis of blight disease management in potato through frontline demonstration. Indian Research Journal of Extension Education 7, 82-84.

Mitra, B., Samajdar, T., 2010. Yield gap analysis of rapeseed and mustard through frontline demonstrations. Agricultural Extension Review 22, 16-17. 
Paul, J., Suri, V.K., Sandal, S.K., Choudhary, A.K., 2011. Evaluation of targeted yield precision model for soybean and toria crops on farmers' fields under sub-humid subtropical NW Himalayas. Communications in Soil Science and Plant Analysis 42, 2452-2460.

Sagar, S.L., Chandra, G., 2004. Frontline demonstration on sesame in West Bengal. Agricultural Extension Review 16, 7-10.

Samui, S.K., Maitra, S., Roy, D.K., Mondal, A.K., Saha, D., 2000.
Evaluation on frontline demonstration on groundnut. Journal of the Indian Society of Coastal Agricultural Research 18, 180-183.

Vaghasia, P.M., Savalia, R.L., Kelaiya, G.R., 2005. Evaluation of frontline demonstrations on groundnut in Saurashtra region of Gujarat. Journal of Oilseeds Research 22, 238-239. 